\title{
Selected Current Sensing Circuits for Motor Control Applications
}

\author{
Wojciech Słowik, Paweł Piątek, Tomasz Dziwiński, Jerzy Baranowski \\ AGH University of Science and Technology, Faculty of Electrical Engineering, Automatics, Computer Science and Biomedical Engineering, \\ al. Mickiewicza 30, 30-059 Kraków, Poland
}

\begin{abstract}
Precise current measurements are essential part of modern motor control algorithms. They are also required in switch mode power converters, safety circuits, current sources, supervisor systems and many other applications. In order to select the right method, it is often required from the designer to have wide knowledge of the appropriate integrated circuit, its parameters and applications. Still increasing requirements for the speed and precision of designing solutions, decreasing voltage levels, power consumption and aspects of EMC compatibility impose often contrary initial conditions.
\end{abstract}

Słowa kluczowe: current sensing, low side, high side, current sense amplifier, instrumentation amplifier, Hall effect sensor

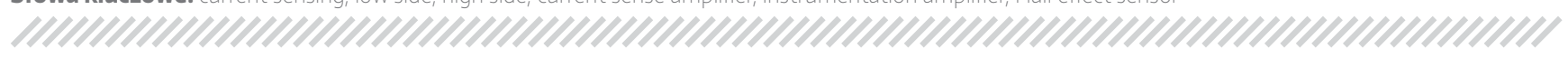

\section{Introduction}

Current measurement in the case of electric motors is the most important thing essential for the implementation of motor control systems (in addition to measuring voltages). Depending on the target application and the complexity of the system we can distinguish at least several methods differing in levels of the complexity, cost and quality of the measurement. Currently, electric motors are used in many fields, ranging from simple fan drive circuits to complex systems like railways drive systems, servomotors, robotics, machines for the CNC and so on.

In the traditional control scheme for three-phase brushless motors, we can distinguish the following places for current measurement (Fig. 1): motor phase currents (yellow stars), power inverter input current (overall input current - red star), the currents in the individual branches of the inverter (green stars). Direct measurement of the phase currents is used in the most complex applications. Indirectly, the same result can be obtained by measuring the currents in the branches of the inverter between the lower keys and system ground. As will be explained later, it is convenient because the current sensor is reference to the ground of the system. Measurement of the motor currents directly on the leads require galvanic isolation. This can be done through the use of current transformer, isolated sigma-delta converters or isolated amplifiers.

There are two basic methods for current measurement: methods based on the measurement of voltage drop across the resistor (shunt resistor) and Hall effect based methods, using the measurement of the magnetic field generated around a conductor passing current.

Autor korespondujący:

Wojciech Słowik, wslowik@agh.edu.pl

\section{Artykuł recenzowany}

nadesłany 1.03.2017 r., przyjęty do druku 30.03.2017 r.

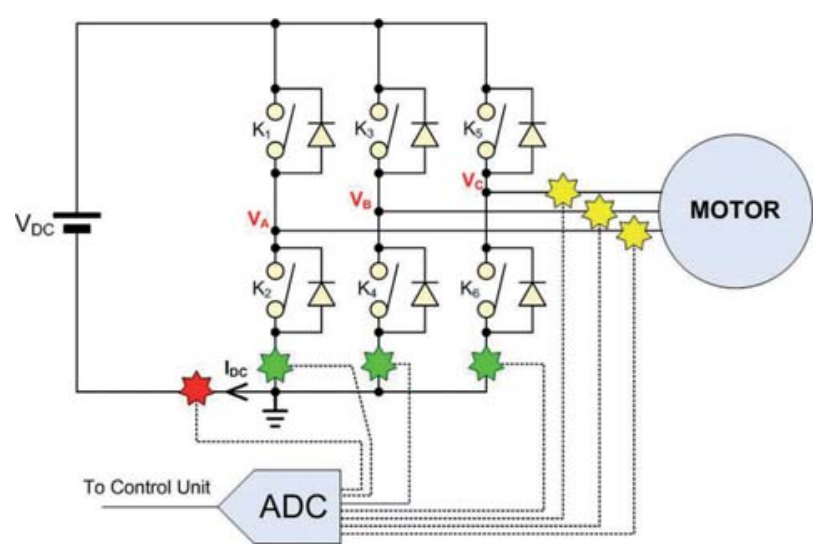

Fig. 1. Most common current sensing points in motor control applications

Rys. 1. Najczęściej stosowane miejsca pomiaru prądu w aplikacjach sterowania silnikami elektrycznymi

The first group of methods is the most common. It is characterized by relative simplicity and low cost of implementation. The method based on the measurement of the magnetic field is readily applicable for measuring currents up to hundreds amperes. For this purpose, the integrated Hall sensors are nowadays commonly used. Although the implementation cost is a little higher, this method has some strong advantages.

Methods using the voltage drop across the shunt resistor utilizes two basic ways: the resistor can be placed from the ground side (Low Side Current Sensing) or the shunt resistor can be placed from the supply voltage side (High Side Current Sensing).

\section{Low Side Current Sensing}

The easiest way to measure the current is to insert in the test system supply rail, a resistor of a small value as shown in Fig. 2. The current passing through the resistor produces a slight vol- 


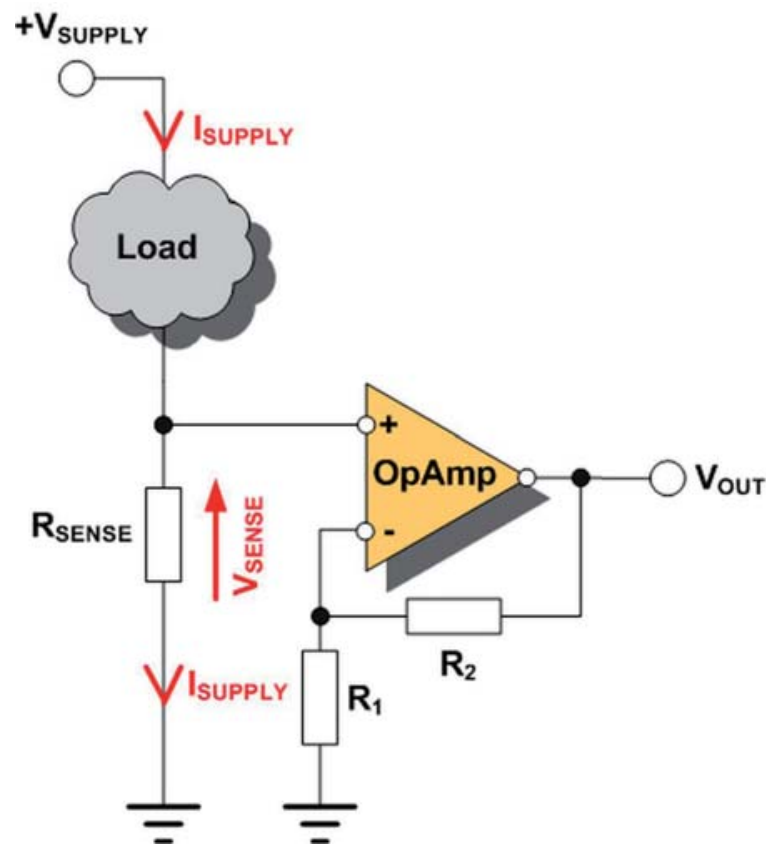

Fig. 2. Low Side Current Sensing

Rys. 2. Pomiar prądu na rezystorze od strony masy

tage drop in accordance with Ohm's law: $U_{\text {SENSE }}=R_{\text {SENSE }} \cdot I_{L O A D}$. In most cases, voltage drop is too small to be directly used for further processing. Therefore, it is often required to use some amplification. Note, that the resistor is connected between the test system and the ground. At first glance, this solution seems to be free of defects - shunt resistor is grounded at one side, so that we can use simple operational amplifier in noninverting configuration in order to amplify small voltage drop proportional to the measured current (it should be also mention that noninverting configuration is in this case the only one solution - we assume that we have a single power supply voltage, and we want to reduce the impact of shunt input amplifier resistance on current measurement). This solution however, has some major drawbacks that cannot always be ignored. The first one results from the presence of voltage drop between the ground and tested system. Consequently, the ground of the system is at non zero potential (at floating potential if the current is variable in time). This can cause incorrect work especially of analog circuits, where the output of the amplifier is taken with respect to ground. Another important drawback is the inability to detect a short circuit in the system under test. If such a condition occurs, the short-circuit current flow from the power supply voltage through the test system to the ground. No current will pass through measuring resistor, so supervisor circuit will not even notice a serious failure in the system. Note also that in this case the common input voltage of the amplifier is close to zero. Therefore, we should pay special attention when choosing amplifier whether the selected model accepts input common mode voltage $V_{C M}$ close to the ground (input rail to rail type of amplifier).

\section{High Side Current Sensing}

The second approach without the disadvantages of the previous method is to place shunt resistor at the side of power supply voltage (Fig. 3). In this case the system under test is at a constant ground potential. This does not disturb proper work of even sensitive analog circuits. Also, the possible fault

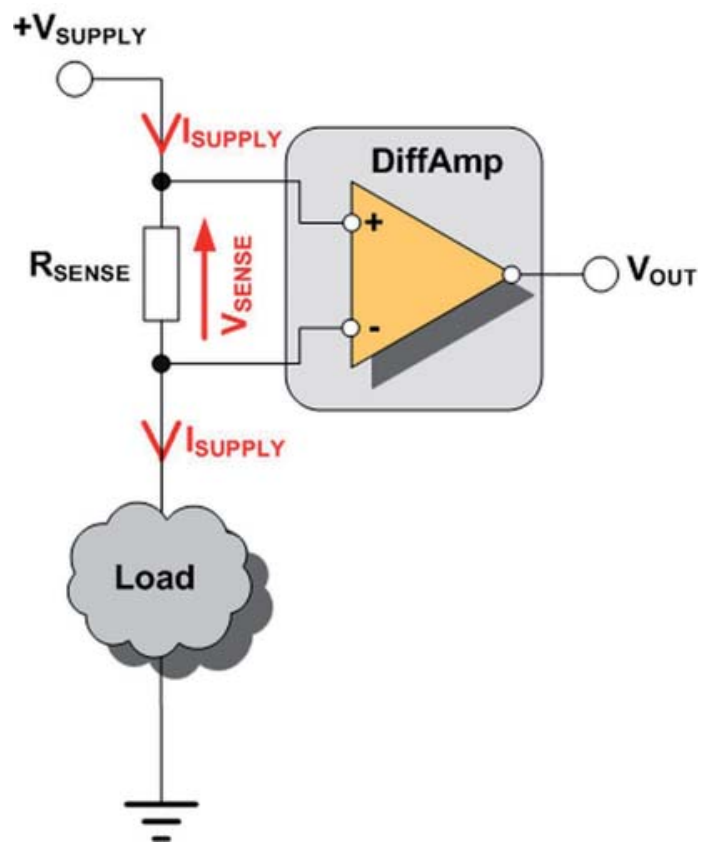

Fig. 3. High Side Current Sensing

Rys. 3. Pomiar prądu na rezystorze od strony zasilania

short circuit to ground current will flow through the measuring resistor, which will be immediately noticed by the supervisor circuit. In this system however, there is significant drawback. While in previous method the measuring resistor was grounded at one side, here both ends of the shunt resistor are at the potential close to the supply voltage (supply voltage can be high in case of power electronic systems, motors, etc.). This creates two serious problems. Firstly, it becomes necessary to use differential amplifier. Secondly, this amplifier must accept high common mode voltage $V_{C M}$ at their inputs. The simplest application of fully differential amplifier is shown in Fig. 3.

The standard difference configuration of the operational amplifier is shown in Fig. 4. Output voltage describes the relationship:

$$
V_{O U T}=\frac{R_{2}}{R_{1}} \cdot\left(V_{I N 1}-V_{I N 2}\right)+V_{R E F}
$$

which is valid when the precise ratio of resistors $R_{2} / R_{1}$ is kept.

It should be noted that the basis of differential operation and achievement of satisfactory values of CMRR (Common Mode Rejection Ratio) is the precise selection of four resistors. In practice, the cost of the resistor with tolerance of $0.1 \%$ may be unacceptable.

Using the formula from References [1]:

$$
C M R R=20 \log \left[\frac{\frac{1}{2} \cdot\left(1+\frac{R_{2}}{R_{1}}\right)}{\frac{\Delta R}{R}}\right]
$$

we can calculate the CMRR values obtained for the manually matched resistors. For example, if $R_{2} / R_{1}=1$, and the resistors would have a tolerance of $0.1 \%$, the $C M R R$ in the worst case would be $54 \mathrm{~dB}$. If the resistors would be $1 \%$, we would obtain $34 \mathrm{~dB}$ of $C M R R$, which of course is in most cases not acceptable. It should also be noted that the values of $R_{1}$ and $R_{2}$ should be much greater than the shunt resistor $R_{\text {SENSE }}$ to avoid 
loading effect. This increases the problem of choosing precise resistance (resistance of the PCB tracks may also be relevant).

Note that if we would like to change a gain of the amplifier it is extremely cumbersome - it requires simultaneous, precise change of two resistors. If the voltage $V_{I N 1}$ and $V_{I N 2}$ are at a high potential (exceeding the amplifier $V_{C M}$ ) we can indeed choose voltage dividers at the inputs of the amplifier (comprised of resistors $R_{1}, R_{2}$, for example $R_{2}=0.1 \cdot R_{1}$ ) that we will be able to measure the small differential voltage at high common voltage, but the circuit gain will also be reduced (10 times for $R_{2}=$ $\left.0.1 \cdot R_{1}\right)$. It may turn out after while that the resulting gain that we have is not enough to detect the weak measured signal. The circuit is complicated even more if we need to measure alternating current - by supplying the amplifier by unipolar manner, we need to ensure proper shift of the output voltage to the half of the supply voltage range to avoid saturation of the amplifier. For example, if the amplifier is powered by a unipolar $5 \mathrm{~V} / \mathrm{GND}$, we should shift the output voltage to $2.5 \mathrm{~V}$ for zero differential input voltage, using $V_{R E F}$ input. This input, however, should be connected to a source with the possibly lowest output impedance, because each serial voltage-sources output impedance will added to the resistance $R_{2}$ and drastically deteriorating the $C M R R$ factor (there is a change of the ratio of precisely matched resistances $R_{2} / R_{1}$ ). In this case, it is necessary to use additional voltage follower between the voltage source output and the $V_{R E F}$ input as it is shown in Fig. 5.

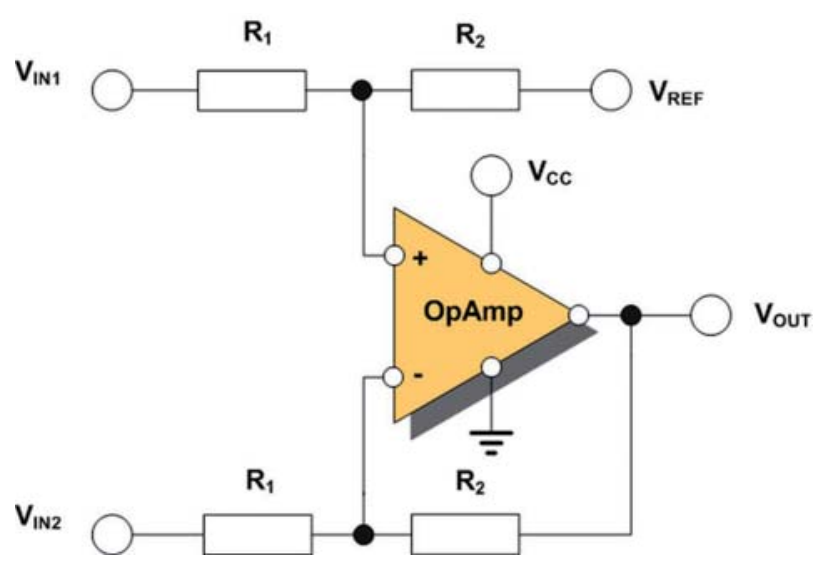

Fig. 4. Difference amplifier with external, precisely paired resistors in order to keep relation $\mathbf{R}_{2} / \mathbf{R}_{1}$ as much as possible

Rys. 4. Wzmacniacz różnicowy z zewnętrznymi, precyzyjnie dobranymi rezystorami w celu precyzyjnego utrzymania stosunku $R_{2} / R_{1}$

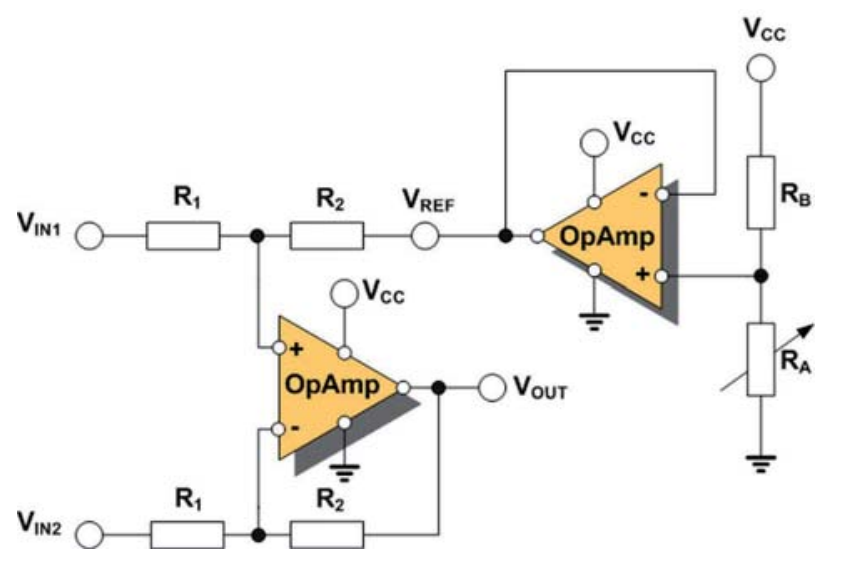

Fig. 5. Difference amplifier output voltage level shifting

Rys. 5. Przesunięcie poziomu napięcia wyjściowego wzmacniacza różnicowego
Too low achievable $C M R R$ for the differential configuration depicted in Fig. 4 encourages to use instrumentation amplifier - InAmp. These kind of amplifiers with differential input and single ended output were designed to amplify very weak differential signals, on the background of strong interfering common mode signals. Instrumentation amplifiers are widely used in sensor signal conditioning for medical or biological applications because of their very high differential gain, high $C M R R$ ratio and the presence of $V_{R E F}$ input to offset the output voltage especially when InAmp is unipolar powered. Simplified internal architecture is presented in Fig. 6 [7].

All components except the resistor $R_{G}$ are integrated inside InAmp structure. The architecture of the amplifier can be divided into two blocks: amplifiers $O A_{1}$ and $O A_{2}$ which serves as amplifiers for differential signal (gain of $1+2 R_{F} / R_{G}$ ) and voltage followers for common mode signal (gain $\times 1$ ). The amplifier $O A_{3}$ is configured as differential amplifier (usually with a gain of $\times 1$ ). Its main role is to remove the common component. Note that this is the same amplifier as shown in Fig. 4. However, due to the integration and laser trimmed resistors $R_{1}, R_{2}$ it is possible to achieve $C M R R$ of $90 \mathrm{~dB}$ or above. Such levels would have never been achievable with manual pairing of external resistors. Due to the smart architecture, the gain is easily adjustable by external resistor $R_{G}$ Usage of instrumentation amplifier seems to be highly desirable in the application of current measurement. Note however, that the amplifier in the considered application is

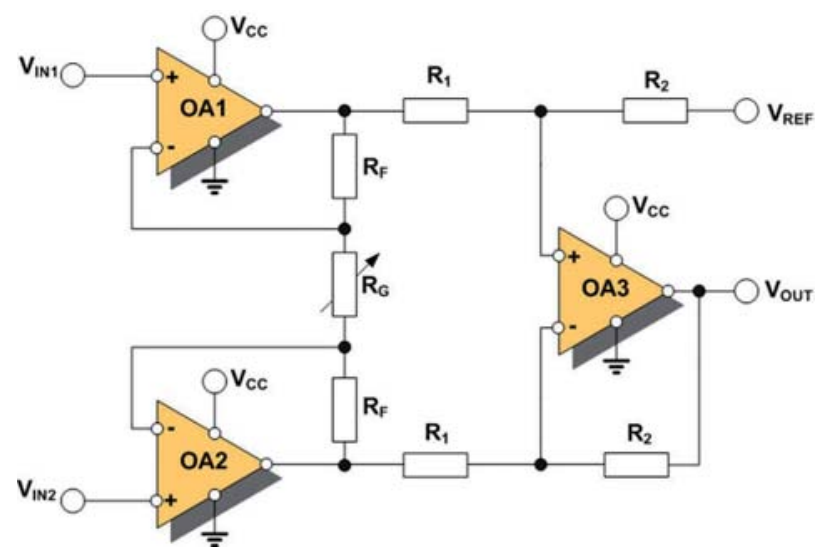

Fig. 6. Internal architecture of Instrumentation Amplifier $\left(R_{G}\right.$ resistor is external)

Rys. 6. Architektura wewnętrzna wzmacniacza pomiarowego (rezystor $R_{G}$ zewnętrzny)

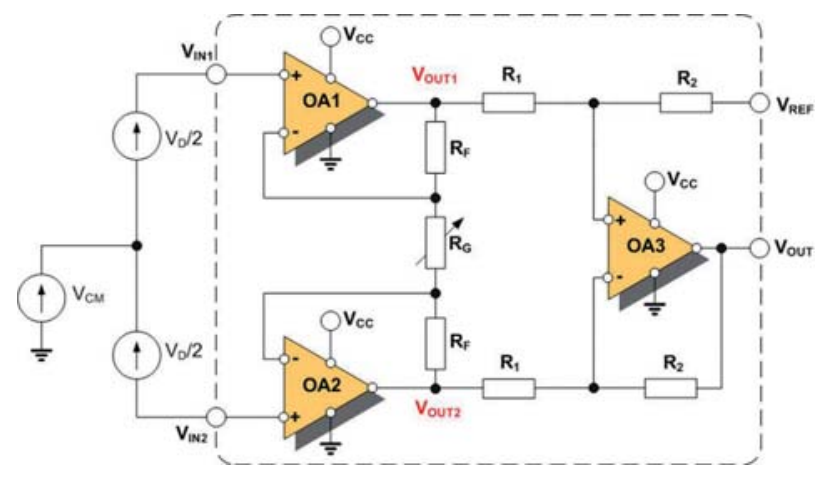

Fig. 7. Instrumentation Amplifier with external signals: common and differential

Rys. 7. Wzmacniacz pomiarowy zasilony sygnałami różnicowymi oraz sygnałem wspólnym 
supplied from a single voltage source. There must be therefore ensured such conditions, that none of the internal amplifiers has never been saturated (both to GND or $\mathrm{V}_{\mathrm{CC}}$ ).

General analysis of the amplifier let us begin by identifying voltages $V_{\text {OUT1 }}$ and $V_{\text {OUT2 }}$ depicted in Fig. 7 .

Considering only common mode component $V_{C M}$, amplifiers $O A_{1}$ and $O A_{2}$ work as voltage followers. Therefore $V_{\text {OUT1 }}=V_{\text {OUT2 }}$ $=V_{C M}$. If the amplifier $O A_{3}$ has all the resistors of equal value, under the formula (1), $V_{\text {OUT }}=0$, which means zero common mode signal amplification, and thus the infinite value of $C M R R$.

On the other hand, if we consider only the differential component $V_{D}$, we see that the amplifiers $O A_{1}$ and $O A_{2}$ work in inverting and non-inverting configuration depending upon which part of the differential signal we consider (superposition: $V_{D} / 2$ and $\left.-V_{D} / 2\right)$. From superposition we determine the formulas:

$$
\begin{gathered}
V_{\text {OUT1 }}=\left(1+\frac{R_{F}}{R_{G}}\right) \cdot V_{I N 1}+\left(-\frac{R_{F}}{R_{G}}\right) \cdot V_{I N 2}=\frac{V_{D}}{2}+\frac{R_{F}}{R_{G}} \cdot V_{D} \\
V_{\text {OUT2 }}=\left(1+\frac{R_{F}}{R_{G}}\right) \cdot V_{I N 2}+\left(-\frac{R_{F}}{R_{G}}\right) \cdot V_{I N 1}=-\frac{V_{D}}{2}-\frac{R_{F}}{R_{G}} \cdot V_{D}
\end{gathered}
$$

Thus, the voltage

$$
V_{R}=V_{\text {OUT1 }}-V_{\text {OUT2 }}=V_{D} \cdot\left(1+2 R_{F} / R_{G}\right)
$$

$O A_{3}$ amplifies voltage $V_{R}=V_{\text {OUT1 }}-V_{\text {OUT2 }}$.

Under the formula (1), output voltage of the amplifier:

$V_{O U T}=\left(\frac{R_{2}}{R_{1}}\right) \cdot V_{R}+V_{R E F}=\left(\frac{R_{2}}{R_{1}}\right) \cdot V_{D} \cdot\left(1+\frac{2 R_{F}}{R_{G}}\right)+V_{R E F}$

If we assume (as it is almost always), that $R_{1}=R_{2}$, we get:

$$
V_{O U T}=\left(1+\frac{2 R_{F}}{R_{G}}\right) \cdot V_{D}+V_{R E F}
$$

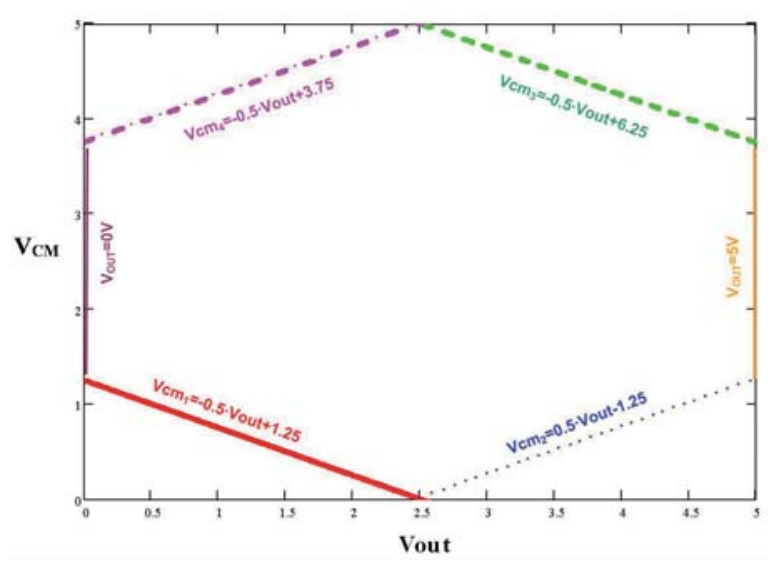

Fig. 8. "Diamond plot" showing relations between $V_{C M}$ and $V_{\text {OUT }}$ for single $5 \mathrm{~V}$ powered instrumentation amplifier with $\mathrm{V}_{\mathrm{REF}}=\mathbf{2 . 5 \mathrm { V }}$ Rys. 8. Wykres typu „Diamond plot” ukazujący relacje pomiędzy $V_{C M}$ oraz $V_{\text {OUT }}$ dla zasilania wzmacniacza $5 \mathrm{~V}$ oraz $V_{\text {REF }}=2,5 \mathrm{~V}$
Thus it can be seen that the differential gain of $V_{D}$ signal can be easily adjusted by the resistor $R_{G}$. Any voltage applied to the $V_{R E F}$ input shifts the output voltage level with the gain $\times 1$. It should also be noted that the amplifier has a very large input impedance, depending on the construction of the input stages (about $10^{9} \Omega$ ).

These considerations do not however, take into account the fact that the InAmp, and thus - all the OpAmps inside are unipolar powered.

Let us analyze, the allowable range of input voltages with the assumed limitations to the supply voltage to $V_{C C}$.

$$
V_{O U T 1}, V_{O U T 2}=V_{C M} \pm\left(K_{D} \cdot \frac{V_{D}}{2}\right)=V_{C M} \pm \frac{V_{O U T}-V_{R E F}}{2}
$$

where $K_{D}$ is a differential gain. To prevent saturation of the amplifiers $O A_{1}, O A_{2}$, voltages $V_{\text {OUT1 }}, V_{\text {OUT2 }}, V_{\text {OUT }}$ should meet the obvious relations:

$$
0<V_{\text {OUT1 }}, V_{\text {OUT2 }}<V_{C C}
$$

$$
0<V_{\text {OUT }}<V_{C C}
$$

i.e.:

$$
0<V_{C M} \pm \frac{V_{O U T}-V_{R E F}}{2}<V_{C C}
$$

If we assume $V_{R E F}=0$ as in the case of bipolar power, from equation (10) we get:

$$
0<V_{C M} \pm \frac{V_{O U T}}{2}<V_{C C}
$$

If we assume $V_{R E F}=V_{C C} / 2$ we get:

$$
0<V_{C M} \pm \frac{V_{\text {OUT }}}{2} \pm \frac{V_{C C}}{4}<V_{C C}
$$

By plotting inequalities (13) along with constraints (9) and (10) for $V_{C C}=5 \mathrm{~V}, V_{R E F}=2.5 \mathrm{~V}$ we obtain plot depicted in Fig. 8.

This kind of plot gives us very important information about relation of the common input voltage as a function of the output

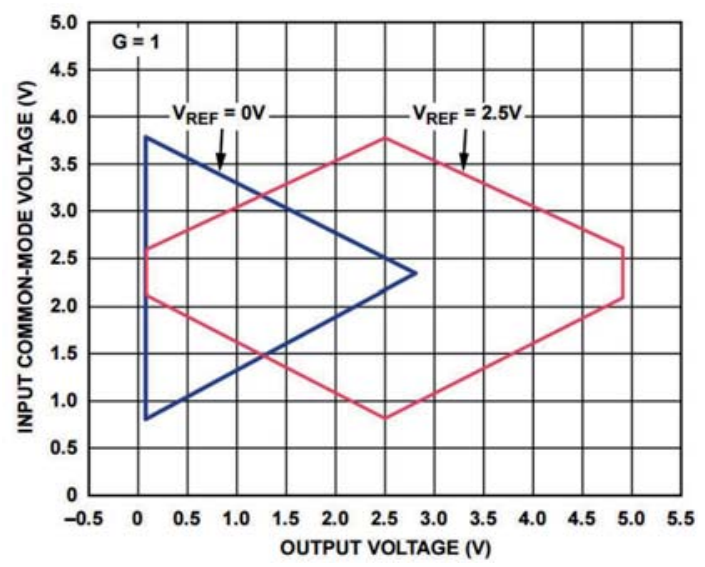

Fig. 9. Example instrumentation amplifier "diamond plot" - AD8422 from Analog Devices [2]

Rys. 9. Przykładowa charakterystyka „Diamond plot” wzmacniacza AD8422 firmy Analog Devices [2] 
voltage $V_{C M}=f\left(V_{\text {OUT }}\right)$. The graph is commonly called "diamond plot", so named because of its shape. Presented in Fig. 9 is an example graph of commercially available amplifier AD8422 from Analog Devices.

From the plot we can read the following information: for $V_{R E F}$ $=2.5 \mathrm{~V}$, if the common input voltage will stay within the range of approximately 2.1-2.6 $\mathrm{V}$, then we will have a full range of output voltage available. For $V_{R E F}=0 \mathrm{~V}$, the widest range of output voltage is available only for $V_{C M} \approx 2.4 \mathrm{~V}$.

In other common voltage ranges, output voltage range is limited because of the saturation of the internal stages.

There are also used monolithic instrumentation amplifiers designed for bi-directional common mode voltage range. An example might be LT1168C type of precision instrumentation amplifier from Linear Technology [6]. It can be bipolar powered from $\pm 2.3 \mathrm{~V}$ up to $\pm 18 \mathrm{~V}$ and its input common-mode voltage range is form $-V_{S}+1.9 \mathrm{~V}$ to $+V_{S}-1.4 \mathrm{~V}$. This type of amplifier has very good parameters like very small voltage unbalance $(80 \mu \mathrm{V})$, low temperature drift of the offset voltage $\left(0.4 \mu \mathrm{V} /{ }^{\circ} \mathrm{C}\right)$ and very high input resistance - larger than $200 \mathrm{G} \Omega$.

\section{Current Sense Amplifiers}

As is apparent from the foregoing, each of the previous methods have certain advantages and disadvantages. In order to facilitate the measurement of current systems and minimize the number of necessary elements to achieve the goal, many leading IC manufacturers have introduced amplifiers called CSA (Current Sense Amplifier). They are ready to use ICs (Integrated Circuits) designed strictly for current measurement using a high side shunt resistor. An exemplary IC from STMicroelectronics TST101 is shown in Fig. 10.

Note that the system may have a higher common mode voltage at the inputs $V_{P}, V_{N}$ than its supply voltage. The principle of operation is as follows: measured current causes a voltage drop across the shunt resistor. This voltage is being applied to the internal operational amplifier, which feedback controls the internal transistor so as to both inputs of the amplifier were balanced. If this condition occurs the voltage across the resistor $R_{G 1}$ will be equal to the voltage across the resistor $R_{\text {SENSE }}$ (assuming zero current consumption of the amplifier input and thus zero voltage drop across the resistor $R_{G 2}$ ). Deriving elementary calculations we are able to determine the value of the output voltage corresponding to the measured current:

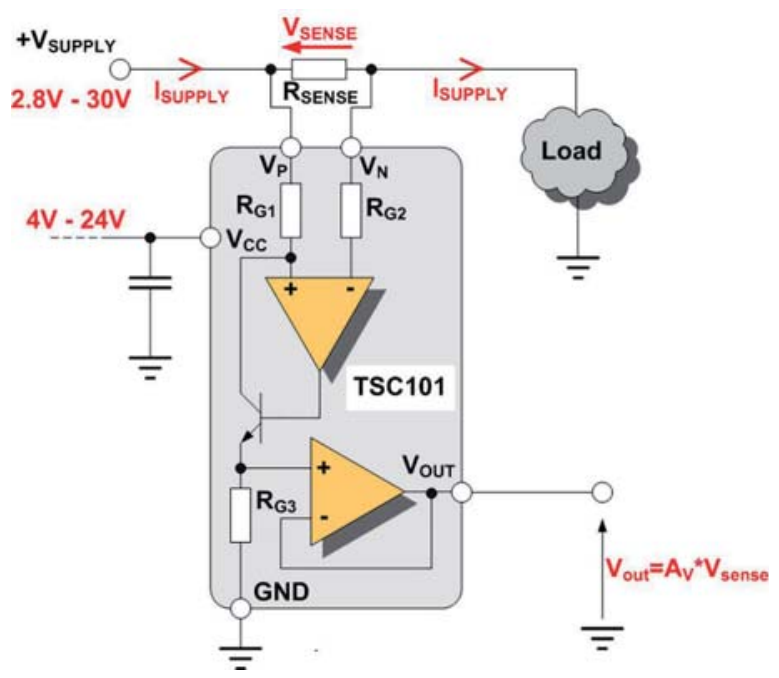

Fig. 10. Example CSA integrated circuit (Current Sense Amplifier) [3] Rys. 10. Przykładowy układ CSA (Current Sense Amplifier) [3]

$$
\begin{gathered}
V_{\text {SENSE }}=R_{\text {SENSE }} \cdot I_{\text {SUPPLY }} \\
V_{S E N S E}=R_{G 1} \cdot I_{1} \\
V_{O U T}=R_{G 3} \cdot I_{1}=R_{G 3} \cdot \frac{V_{S E N S E}}{R_{G 1}}=\frac{R_{G 3}}{R_{G 1}} \cdot R_{S E N S E} \cdot I_{S U P P L Y}
\end{gathered}
$$

The ratio $R_{G 3} / R_{G 1}$ setting the gain is fixed at the production stage to the values of $20 \mathrm{~V} / \mathrm{V}, 50 \mathrm{~V} / \mathrm{V}, 100 \mathrm{~V} / \mathrm{V}$, depending on the version of the chip.

\section{Hall Effect-Based Linear Current Sensors}

As it was previously mentioned, all resistive methods insert unavoidable voltage drop. Of course it is also the essence of the methods. However, if we would like to measure high currents, the voltage drop across shunt resistor in accordance with current flowing through it may causes significant power losses according to $I^{2} R$ law. Moreover, if power line voltage is very high or negative related to ground, it may turn out to be impossible to measure current without isolation. In this situation very attractive solution is to use Hall effect based magnetic field sensors. Figure 11 presents exemplary integrated circuit ACS712 from Allegro Microsystems.

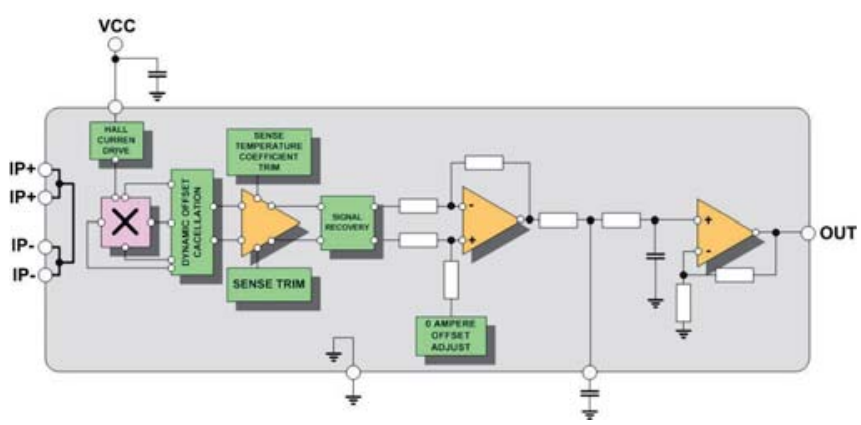

Fig. 11. Example Hall effect-based current sensor [4]

Rys. 11. Przykładowy układ czujnika Hallotronowego [4]

It is fully integrated Hall sensor together with all necessary signal conditioning circuits. Chip has built in piece of wire, which conduct measured current. Practically there is no voltage drop (exactly $1.2 \mathrm{~m} \Omega$ internal conductor resistance) and high current side is isolated $\left(2.1 \mathrm{kV}_{\mathrm{RMS}}\right)$ from rest of electronic circuits, therefore it is possible to measure current even at very high potential. Circuit is powered from $5 \mathrm{~V}$ and its output signal is proportional to measured current with sensitivity depending on the version of the chip.

\section{Isolation Amplifiers}

In situations where high voltage between grounds can occur, there is a need for galvanic isolation between circuits (what is, for example, necessary in case of biomedical systems) or simply to break ground loops, the natural choice becomes isolation amplifier [6]. Isolation between two parts of circuit can be achieved by three ways:

- optical coupling - consist of LED diode and photodiode, isolation performed by electromagnetic fields (light radiation),

- transformer coupling - most common isolation technique [5], isolation performed by magnetic field, 


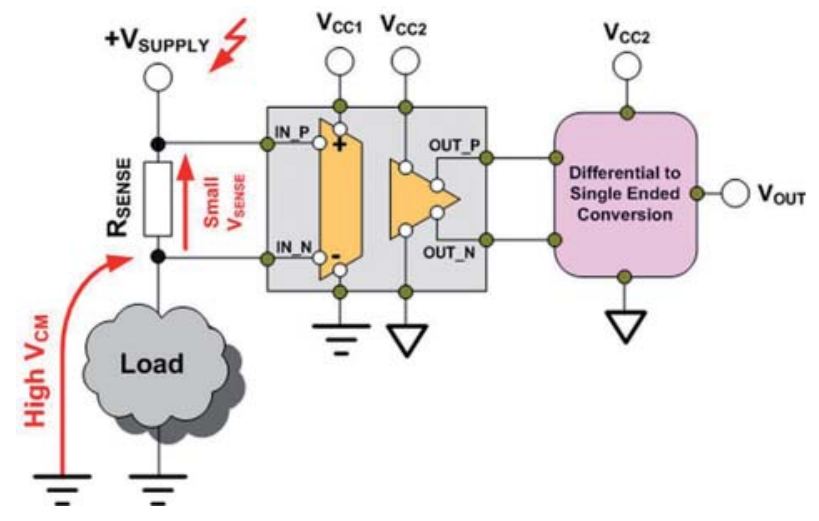

Fig. 12. Application of current sensing using isolated differential amplifier

Rys. 12. Aplikacja pomiaru prądu z użyciem różnicowego wzmacniacza izolowanego

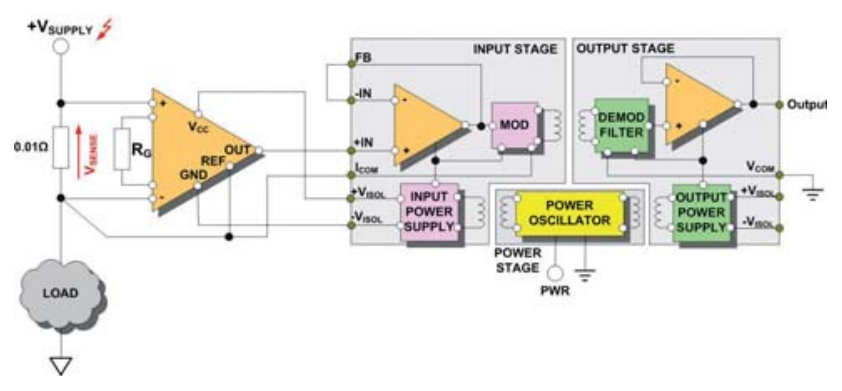

Fig. 13. Current sensing for motor control application [5]

Rys. 13. Pomiar prądu w aplikacji sterowania silnikiem

- capacitive coupling - using small high voltage capacitors, isolation performed by electric field.

In optical or capacitive coupling, both high voltage and low voltage sides need power supply. Hence, it is very important matter to use (for high voltage side) isolated power supply or take power directly from high voltage side. In the latter case, we have to note that high voltage side of power supply for amplifier ( $V_{C C 1}$ at Fig. 12) is also restricted to, for example $+5 \mathrm{~V}$. Also inputs $I N_{-} P$ and $I N \_N$ voltages are restricted, for example from $G N D_{1}+0.1 \mathrm{~V}$ to $V_{C C 1}-0.1 \mathrm{~V}$. If we utilize low side current sensing there is no particular problem. Problem occurs when we want to measure small differential signal with high common mode signal as presented on Fig. 12.

In this case we have to ensure two things: proper high side power supply for amplifier and proper voltages for $I N \_P$ and $I N \_N$ with respect to power supply $V_{C C 1}, G N D_{1}$. In this situation it is better to choose isolated amplifier with transformer coupling. Here, isolated power supply for high side is taken from low side or common side through transformer. Figure 13 presents exemplary motor control current sensing application where small differential signal across $0.01 \Omega$ shunt resistor is measured with present of high common mode voltage. Input instrumentation amplifier is powered from isolated "floating" power supply obtained by transformer coupling.

\section{Current transformer}

According to fundamental transformer formula

$$
\frac{V_{S}}{V_{P}}=\frac{I_{P}}{I_{S}}=\frac{n_{S}}{n_{P}}=n
$$

where: $n$ - transformer turn ratio; $n_{P}$ - number of turns of primary windings; $n_{S}$ - number of turns of secondary windings; $V_{P}$ - primary voltage; $V_{S}$ - secondary voltage; $I_{P}$ - primary current; $I_{S}$ - secondary current.

The secondary current is directly proportional to primary one: $I_{S}=I_{P} / n$. Therefore, we can use toroidal core with many secondary turns and one primary turn through which measured current flows (Fig. 14). Because of the fact that the primary and secondary windings are galvanically isolated they can be at a different voltage levels. Therefore, current transformer is very convenient device for measuring high and very high currents in the present of high or very high voltages. It should be noted that the secondary winding should always work in a short circuit state. Opening the secondary circuit can be dangerous because of the possibility of high voltage being induced.

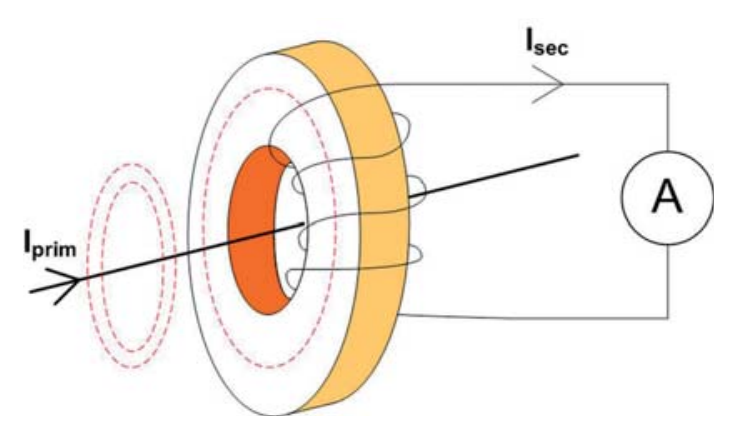

Fig. 14. Current transformer

Rys. 14. Przekładnik prądowy

The main drawback of this solution is that it can measure only AC currents.

In practical applications, at the secondary side of the transformer, it is common to use burden resistor which converts secondary current to voltage drop. Next, voltage across resistor is directly measured or amplify and directed for further processing.

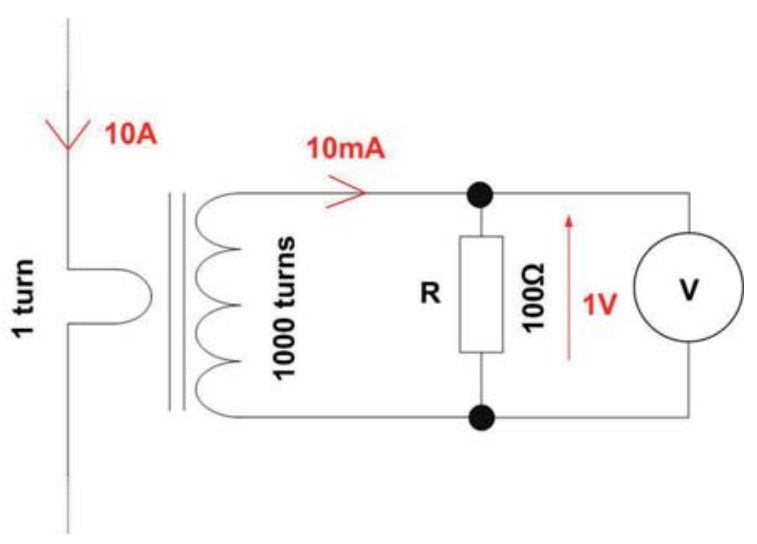

Fig. 15. Current transformer together with burden resistor Rys. 15. Przekładnik prądowy z rezystorem obciążenia

\section{Conclusions}

As can be seen, there are many different topologies and methods of measuring current differing in complexity, the cost of implementation and accuracy. For applications where precision current measurement is not the primary thing, the most frequently chosen is the cheapest solution i.e. one or two shunt resistors. In the case of precision systems, it is often required to have electrical isolation and an appropriate control dynamics what is not easy due to the added phase delay introduced by the isolation and filter circuits. 
However, to be able to choose (among a wide variety of application) the one, that fulfill the project expectations, the designer should know all of the available alternative methods, and fully understand how their works.

Below it is presented a summary of discussed methods.

Tab. 1. Pros and Cons of Low Side Current Sensing

Tab. 1. Zalety i wady pomiaru prądu na rezystorze od strony masy

\begin{tabular}{|c|c|}
\hline \multicolumn{2}{|c|}{ Low Side Current Sensing } \\
\hline Pros & Cons \\
\hline Simplest & Distorted ground potential \\
\hline Low cost & Unable to detect short circuit to ground \\
\hline $\begin{array}{c}\text { Easy signal amplification } \\
\text { Common mode voltage }\end{array}$ & Need to have rail-rail op-amp \\
\hline near to ground & \\
\hline $\begin{array}{c}\text { Suitable for DC/AC } \\
\text { measurements }\end{array}$ & No galvanic isolation between circuits \\
\hline
\end{tabular}

Tab. 2. Pros and Cons of High Side Current Sensing

Tab. 2. Zalety i wady pomiaru prądu na rezystorze od strony zasilania

\begin{tabular}{|c|c|}
\hline \multicolumn{2}{|c|}{ High Side Current Sensing } \\
\hline Pros & Cons \\
\hline Low cost & Difficult signal amplification \\
\hline $\begin{array}{c}\text { Able to detect short } \\
\text { circuit to ground } \\
\text { Do not disturb system } \\
\text { ground }\end{array}$ & Need to have differential amplifier \\
\hline $\begin{array}{c}\text { Suitable for DC/AC } \\
\text { measurements }\end{array}$ & Need to have rail-rail op-amp \\
\hline & Only for low currents \\
\hline
\end{tabular}

Tab. 3. Pros and Cons of Current Sense Amplifiers

Tab. 3. Zalety i wady pomiaru prądu za pomocą układów CSA

\begin{tabular}{|c|c|}
\hline \multicolumn{2}{|c|}{ Current Sense Amplifiers } \\
\hline Pros & Cons \\
\hline Low cost & Fixed specific gains \\
\hline $\begin{array}{c}\text { No external components } \\
\text { needed }\end{array}$ & Only for low currents due to power $I^{2} R$ \\
\hline $\begin{array}{c}\text { Able to detect low dif- } \\
\text { ferential signal with high } \\
\text { common voltage present }\end{array}$ & No galvanic isolation between circuits \\
\hline $\begin{array}{c}\text { Fully integrated solution } \\
- \text { small area on PCB }\end{array}$ & \\
\hline Reliability & \\
\hline
\end{tabular}

Tab. 4. Hall based effect integrated sensors

Tab. 4. Zalety i wady pomiaru prądu za pomocą czujników hallotronowych

\begin{tabular}{|c|c|}
\hline \multicolumn{2}{|c|}{ Hall based effect integrated sensors } \\
\hline Pros & Cons \\
\hline Fully integrated chip & Fixed specific gains \\
\hline Medium cost & $\begin{array}{l}\text { May be susceptible } \\
\text { to interference from } \\
\text { surrounding magnetic } \\
\text { fields }\end{array}$ \\
\hline \multicolumn{2}{|l|}{$\begin{array}{c}\text { Practically no inserted voltage drop in } \\
\text { power rail }\end{array}$} \\
\hline \multicolumn{2}{|l|}{$\begin{array}{c}\text { Able to detect low differential signal } \\
\text { with very high common voltage present }\end{array}$} \\
\hline \multicolumn{2}{|l|}{ Galvanic isolation } \\
\hline \multicolumn{2}{|l|}{ No external components needed } \\
\hline \multicolumn{2}{|l|}{ Also for high currents } \\
\hline \multicolumn{2}{|l|}{ Temperature compensation } \\
\hline \multicolumn{2}{|l|}{$\begin{array}{l}\text { May have digital interface to } \\
\text { microprocessor systems }\end{array}$} \\
\hline \multicolumn{2}{|l|}{ Suitable for DC/AC measurements } \\
\hline Reliability & \\
\hline
\end{tabular}

Tab. 5. Pros and Cons of Isolation Amplifiers (IsoAmp)

Tab. 5. Zalety i wady pomiaru prądu za pomocą wzmacniaczy izolowanych

\begin{tabular}{|c|c|}
\hline \multicolumn{2}{|c|}{ Isolation Amplifiers (IsoAmp) } \\
\hline Pros & Cons \\
\hline $\begin{array}{l}\text { Galvanic isolation } \\
\text { between circuits }\end{array}$ & High cost \\
\hline $\begin{array}{l}\text { Able to detect low } \\
\text { differential signal with } \\
\text { very high common signal } \\
\text { present }\end{array}$ & $\begin{array}{l}\text { Only for low currents due to power } \\
\text { losses } I^{2} R\end{array}$ \\
\hline \multirow[t]{4}{*}{$\begin{array}{l}\text { Breaking ground loops - } \\
\text { accurate measurement }\end{array}$} & $\begin{array}{l}\text { In practice needs additional } \\
\text { components }\end{array}$ \\
\hline & May need isolated DC/DC converter \\
\hline & $\begin{array}{c}\text { Difficult to implement parasitic power } \\
\text { supply for high side in high side } \\
\text { current scenario }\end{array}$ \\
\hline & $\begin{array}{l}\text { May be susceptible to interference } \\
\text { from surrounding magnetic fields } \\
\text { (inductance coupling), electric field } \\
\text { (capacitive coupling) }\end{array}$ \\
\hline
\end{tabular}

Tab. 6. Pros and Cons of Current transformer

Tab. 6. Zalety i wady pomiaru prądu za pomocą przekładników prądowych

\begin{tabular}{|c|c|}
\hline \multicolumn{2}{|c|}{ Current transformer } \\
\hline Pros & Cons \\
\hline Galvanic isolation between circuits & $\begin{array}{c}\text { Only for AC } \\
\text { measurements }\end{array}$ \\
\hline Reliability & \\
\hline Suitable for very high currents & \\
\hline
\end{tabular}




\section{References}

1. Lokere K., Hutchison T., Zimmer G., Precision Matched Resistors Automatically Improve Differential Amplifier CMRR - Here's How. Linear Technology Design Note 1023, http://cds.linear.com/docs/en/design-note/dn1023f.pdf

2. AD8422 - High Performance, Low Power, Rail-to-Rail Precision Instrumentation Amplifier. Analog Devices datasheet; http://www.analog.com/media/en/technical-documentation/data-sheets/AD8422.pdf

3. TSC101 - High side current sense amplifier. STMicroelectronics datasheet, http://www.st.com/content/ccc/resource/technical/document/datasheet/group2/df/85/34/ d4/87/18/46/87/CD00153725/files/CD00153725.pdf/ jcr:content/translations/en.CD00153725.pdf

4. ACS712 - Fully Integrated, Hall Effect-Based Linear Current Sensor IC with $2.1 \mathrm{kV}_{\mathrm{RMS}}$ Isolation and a Low-Resi- stance Current Conductor. Allegro Microsystems datasheet; http://www.allegromicro.com/en/Products/Current-Sensor-ICs/Zero-To-Fifty-Amp-Integrated-Conductor-SensorICs/ACS712.aspx

5. Analog Isolation Amplifiers, MT-071, Analog Devices, http://www.analog.com/media/en/training-seminars/ tutorials/MT-071.pdf

6. LT1168 - Low Power, Single Resistor Gain Programmable, Precision Instrumentation Amplifier. Linear Technology datasheet; http://cds.linear.com/docs/en/ datasheet/1168fa.pdf

7. Horowitz P., Hill W., The Art of Electronics. Cambridge University Press, 1989

8. Sedra A.S., Smith K.C., Microelectronic circuits, Oxford University Press, 2009.

\section{Wybrane metody pomiaru prądu w aplikacjach silników elektrycznych}

Streszczenie: The control system is a cascade of three tanks of INTECO. They are used to control two of them. Two algorithms of water level control are used: two single dimensional model predictive control (MPC) algorithms, one for each tank, and a multi-dimensional MPC controlling both tanks simultaneously. A comparative analysis of developed control algorithms for variable set-point trajectory.

Keywords: pomiar prądu, wzmacniacz pomiarowy, wzmacniacz instrumentalny, czujnik Halla, silnik bezszczotkowy

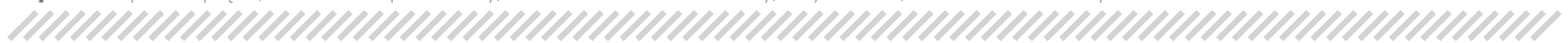

\section{Wojciech Słowik, M.Sc.}

Eng

wslowik@agh.edu.pl

Wojciech Słowik holds a M.Sc. Eng. in Electronics and Telecommunications from the AGH University of Science and Technology in Krakow. Currently he is Ph.D. candidate in the field of Control Engineering. Recent research topics are concerned on modelling, simulation and control of dynamic systems with emphasis on vector control of electric machines

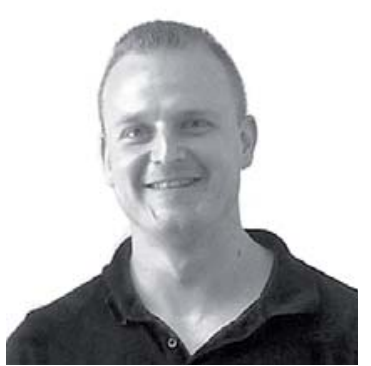

\section{Tomasz Dziwiński, MSc Eng. tdz@agh.edu.p}

Tomasz Dziwiński is currently pursuing the Ph.D. degree at the Department of Automatics and Biomedical Engineering, $\mathrm{AGH}$ University of Science and Technology, Krakow, Poland, in agreement with the KIC InnoEnergy International PhD School coordinated by the KTH Royal Institute of Technology, Stockholm, Sweden. He is intere-

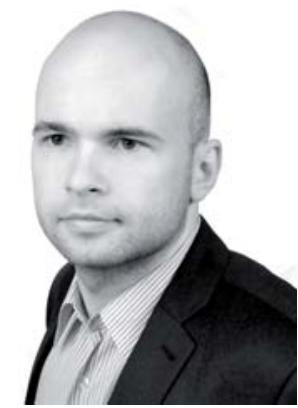
sted in embedded control systems based on digital signal processors, microcontrollers, and FPGA, with a particular focus on power electronic systems. He is involved in the project at the European Institute of Innovation and Technology's Knowledge and Innovation Community. He is also a member of the IEEE Control System Society and the IEEE Power and Energy Society.

Jerzy Baranowski, Ph.D.

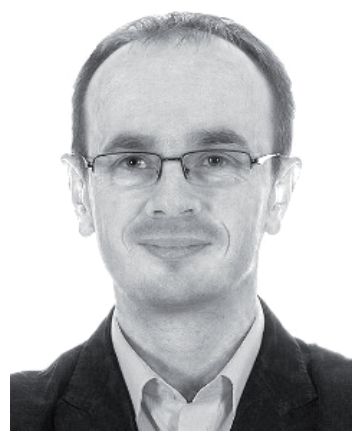

\section{Paweł Piątek, Ph.D.}

\section{ppi@agh.edu.p}

Assistant Professor in the Department of Automatics and Biomedical Engineering at AGH University of Science and Technology in Krakow. The research topics are concerned on the digital control, design and development of real-time control systems and design and application of non-integer order subsystems in control systems.

\section{jb@agh.edu.pl}

Jerzy Baranowski has obtained M.Sc. in 2006 and Ph.D. in 2010 in Automatic Control at AGH University of Science and Technology. His research interests include fractional calculus, approximation theory, numerical methods and data analysis. From 2010 he works as an assistant professor at Department of Automatics and Biomedical Engineering at $\mathrm{ACH}$.

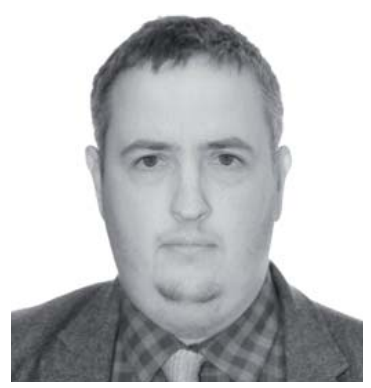

